\title{
Teacher Learning and Instructional Change: How Formal and On- the-Job Learning Opportunities Predict Change in Elementary School Teachers' Practice
}

Leigh Mesler Parise

James P. Spillane

Follow this and additional works at: https://repository.upenn.edu/cpre_articles

Part of the Curriculum and Instruction Commons, Educational Assessment, Evaluation, and Research Commons, and the Teacher Education and Professional Development Commons

\section{Recommended Citation}

Parise, Leigh Mesler and Spillane, James P., "Teacher Learning and Instructional Change: How Formal and On-the-Job Learning Opportunities Predict Change in Elementary School Teachers' Practice" (2010). CPRE Journal Articles. 6.

https://repository.upenn.edu/cpre_articles/6

View on the CPRE website.

This paper is posted at ScholarlyCommons. https://repository.upenn.edu/cpre_articles/6

For more information, please contact repository@pobox.upenn.edu. 


\title{
Teacher Learning and Instructional Change: How Formal and On-the-Job Learning Opportunities Predict Change in Elementary School Teachers' Practice
}

\author{
Abstract \\ Recent education reform has emphasized the importance of teacher learning in improving classroom \\ instruction and raising student achievement. This article focuses on teachers' learning opportunities, \\ including formal professional development and on-the-job learning that occurs through interactions with \\ colleagues. Using data from 30 elementary schools in a mid-sized urban school district, the authors \\ concurrently explore the relationships between teachers' formal professional development and on-the-job \\ learning opportunities and instructional change. Results suggest that formal professional development \\ and on-the-job opportunities to learn are both significantly associated with changes in teachers' \\ instructional practice in mathematics and English language arts. \\ Disciplines \\ Curriculum and Instruction | Educational Assessment, Evaluation, and Research | Teacher Education and \\ Professional Development
}

\section{Comments}

View on the CPRE website. 


\section{Teacher Learning and Instructional Change: How Formal and On-the-Job Learning Opportunities Predict Change in Elementary School Teachers' Practice}

\author{
Leigh Mesler Parise \\ James P. Spillane \\ Northwestern University
}

The Elementary School Journal Volume 110, Number 3

(C) 2010 by The University of Chicago. All rights reserved. 0013-5984/2010/11003-0004\$10.00

\begin{abstract}
Recent education reform has emphasized the importance of teacher learning in improving classroom instruction and raising student achievement. This article focuses on teachers' learning opportunities, including formal professional development and on-the-job learning that occurs through interactions with colleagues. Using data from 30 elementary schools in a midsized urban school district, the authors concurrently explore the relationships between teachers' formal professional development and on-the-job learning opportunities and instructional change. Results suggest that formal professional development and on-the-job opportunities to learn are both significantly associated with changes in teachers' instructional practice in mathematics and English language arts.
\end{abstract}

Recent education reform in the United States has increasingly defined acceptable levels of mastery for students and centered on holding schools accountable for student outcomes. As one strategy for raising student achievement, policymakers have focused on improving the quality of public school teachers (Borko, 2004; Corcoran, 1995b; Desimone, Porter, Garet, Yoon, \& Birman, 2002; Garet, Porter, Desimone, Birman, \& Yoon, 2001; Lieberman, 1995). Some policy initiatives focus on improving the quality of teachers entering the profession through state certification tests, more stringent degree requirements, and recruitment efforts. At the same time, increased accountability pressure on schools requires learning and change for the thousands of teachers already in service, as they are pressed to implement new instructional approaches in order to raise student achievement (Cohen \& Barnes, 1993; Cohen \& Hill, 
2002; Drake, Spillane, \& Hufford-Ackles, 2001; Garet et al., 2001; Wilson \& Berne, 1999). There is great faith among school reformers and education researchers that augmenting the learning opportunities of practicing teachers will enhance teacher performance and lead to improved student outcomes (Borko, 2004). However, the extent to which teachers' learning opportunities facilitate change in their classroom practice remains unclear. This study explores the empirical relationship between teachers' learning opportunities and changes in their instructional practice.

Seeking to understand the kinds of learning opportunities to which teachers have access, educational researchers have followed two somewhat distinct lines of research. The first has focused on teachers' formal learning opportunities, including structured professional development activities and graduate education (Borko, 2004; Desimone, Porter, Garet et al., 2002; Garet et al., 2001; Guskey, 2002); the second line of research has centered on teachers' onthe-job learning and explored aspects of schools' organizational conditions that may affect teacher learning and change (Bryk, Camburn, \& Louis, 1999; Louis, Marks, \& Kruse, 1996; McLaughlin \& Talbert, 2001; Scribner, Cockrell, Cockrell, \& Valentine, 1999; Wilson \& Berne, 1999). While much of this work has been descriptive, researchers in both areas have begun to determine which learning opportunities are most effective at facilitating change. However, these lines of research remain separate in the empirical literature, which is problematic for both policy and practice because it is unclear whether time and money should be spent on expanding teachers' formal professional development, on working to better enable teachers to learn from their colleagues on the job, or on some combination of the two approaches.

This study seeks to marry these two lines of research by concurrently exploring the empirical links between both formal and on-the-job learning opportunities and teacher change. We begin with a review of the literature on teachers' formal and onthe-job learning opportunities, as well as the organizational conditions that may affect teacher learning. In our article, we use the term formal learning opportunities to refer to subject-specific professional development sessions, out-of-school teacher networks, and coursework in math and English. On-the-job learning opportunities refer to interactions with colleagues around teaching and learning, including conversations about instruction, peer observation and feedback, and advice seeking about instruction. After reviewing the literature, we describe the methodology used to analyze the relationship between teacher learning opportunities and teacher change in mathematics and English language arts (ELA) teaching practice for elementary school teachers in a mid-sized urban school district. Finally, we report our main findings, which suggest that both formal professional development and teachers' on-thejob learning opportunities are statistically significant predictors of teacher change in math and ELA instruction. We conclude with a discussion of the implications of our findings for policy and practice.

\section{Empirical and Theoretical Anchors}

Our work is anchored in literature addressing teachers' opportunities to learn, including their formal professional development and the learning opportunities afforded by their interactions with colleagues on the job. A major challenge in the existing literature is that empirical studies of professional development remain separate from studies of teachers' on-the-job learning, though a number of theoretical pieces have jointly discussed them (e.g., Corcoran, 1995a; Putnam \& Borko, 2000). As a result, empirical research on teachers' opportunities to learn lacks a cohesive and comprehensive framework for understanding and integrating the various learning opportunities that may affect teacher practice. In ad- 
dition, although some studies have taken subject matter into consideration by narrowing their scope to a single curricular domain, work on formal and on-the-job learning opportunities fails to make clear if or how teachers' opportunities to learn may have differential effects by school subject. In this section, we explore the extant literature, arguing that these two lines of research must be bridged in order to further our understanding of teacher learning and change.

\section{Formal Learning Opportunities}

Over the last 20 years, amid calls for changes in teaching practice and mounting efforts to increase the professionalization of teaching, reformers and educators have worked to expand professional development opportunities for teachers (Wilson \& Berne, 1999). One example of policymakers' faith that increasing teacher participation in formal learning opportunities will help produce desirable teacher and student outcomes is the requirement in the No Child Left Behind Act of 2001 that states ensure the availability of high-quality professional development for teachers in order to improve classroom instruction (Borko, 2004). In addition, state and district policies require teachers to participate in formal learning opportunities, with the modal state requirement being 120 hours over 5 years (Hill, 2007). States also often require that teachers receive master's degrees, allow graduate coursework to count toward recertification, and provide strong financial incentives for acquiring advanced degrees (Goldhaber \& Brewer, 1998; Hill, 2007). While it is difficult to get an exact estimate of expenditures on teachers' formal professional development (Corcoran, 1995a), schools, districts, states, and the federal government spend at least millions, and likely billions, of dollars on professional development for teachers (Borko, 2004). This is a huge investment for which we know little about returns (Rice, 2001).
Given the increased policy and fiscal emphasis on using formal learning opportunities to facilitate teacher change, this section addresses the types of formal learning opportunities teachers experience and the relationships between formal learning opportunities and changes in teacher practice and student achievement. The literature suggests that the majority of teachers' formal learning opportunities are in the form of workshops, special courses, graduate coursework, and in-service days or conferences devoted to training teachers in a specific set of ideas, techniques, or materials (Desimone, Porter, Garet et al., 2002; Garet et al., 2001; Hill, 2007; Little, 1993; NCES, 2005). These opportunities traditionally follow what Little (1993) termed the "training paradigm," in that they occur outside of teachers' classrooms at scheduled times and are led by an expert seeking to train, or communicate new information to, groups of teachers (Corcoran, 1995a; FeimanNemser, 2001). However, as discussed below, this type of professional development is not likely to facilitate change in teacher practice.

Although most of teachers' formal learning opportunities follow the training paradigm, teachers are increasingly participating in other types of formal professional development that offer markedly different opportunities. Referred to as "reform professional development" by Garet, Desimone, and colleagues (Desimone, Porter, Garet et al., 2002; Garet et al., 2001; Porter, Garet, Desimone, Yoon, \& Birman, 2000), such opportunities frequently relate more closely to teachers' classroom contexts than traditional activities, often involve active participation and collaboration between teachers, and may take place during the regular school day in teachers' classrooms or schools (Desimone, Porter, Garet et al., 2002; Garet et al., 2001). Reform professional development may involve organized teacher study groups or networks, committees, mentoring, internships, and resource centers (Garet et al., 2001). Al- 
though these types of learning opportunities have become more widely available to teachers in recent years, the majority of teachers do not participate in any reformtype formal learning opportunities (Garet et al., 2001; NCES, 2005; Porter et al., 2000).

A significant amount of work has focused on describing the types of formal learning opportunities to which teachers have access, but considerably less research has linked these opportunities to teacher change and student achievement. While this work suggests that most of the professional development that teachers receive, particularly graduate coursework and single workshops that follow the training paradigm, is not consistently linked to changes in classroom practice (Cohen \& Hill, 2002; Garet et al., 2001), it has also identified certain characteristics of formal learning opportunities that make them more likely to facilitate learning and change. Specifically, activities are most effective at fostering teacher change when they involve collective participation of teachers from the same school, grade, or subject, are linked to teachers' on-going daily activities, provide active learning opportunities, and are contentspecific (Desimone, Porter, Birman, Garet, \& Yoon, 2002; Garet et al., 2001, 2008). In general, reform activities are more likely than traditional activities to include these attributes and they tend to be more successful at fostering change in teaching practice (Birman, Desimone, Porter, \& Garet, 2000; Desimone, Porter, Garet et al., 2002; Garet et al., 2001).

With the exception of Garet and colleagues' 2008 study of reading professional development, most of the recent empirical work regarding the effects of formal professional development on teacher change has focused on mathematics. By exploring the effects of subject-specific professional development on teacher change, these studies have taken seriously the work of Stodolsky, Siskin, and others (e.g., Siskin, 1991; Stodolsky, 1988; Stodolsky \& Grossman, 1995) who have suggested that the subject matters when it comes to teacher practice. However, it remains unclear whether the aforementioned activities help foster change similarly across all subject areas, or if, for example, certain opportunities better facilitate learning in math than in ELA.

While fewer studies have focused on the relationship between teachers' formal learning opportunities and student achievement, there is some evidence linking higher student math achievement with teacher participation in sustained formal professional development that is grounded in content-specific pedagogy (Carpenter, Fennema, Peterson, Chiang, \& Loef, 1989; Darling-Hammond, 2000; McCutchen et al., 2002; Saxe, Gearhart, \& Nasir, 2001) and well aligned with policy changes (Cohen \& Hill, 2002; Hill, 2007). While empirical work is beginning to reveal which types of activities may be most effective at influencing teacher and student outcomes, the fact remains that the vast majority of the formal learning opportunities in which teachers participate are the kind of one-shot training sessions that research suggests are not likely to facilitate teacher learning and change (Desimone, Porter, Garet et al., 2002; Hill, 2007; NCES, 2005).

\section{On-the-Job Learning Opportunities and Organizational Conditions}

While formal learning opportunities have taken center stage in the policy arena, some researchers have also focused on how teachers learn from their colleagues on the job, outside of formal professional development activities. Work addressing on-thejob learning opportunities suggests that learning is fostered when professionals work alongside others (Eraut \& Hirsh, 2007) asking questions and gathering information (Eraut \& Hirsh, 2007; Frank, Zhao, \& Borman, 2004), observing colleagues (Eraut, 2004), and giving and receiving feedback (Eraut \& Hirsh, 2007). In this section we review recent scholarship on teachers' 
on-the-job interactions with coworkers and the organizational conditions that may affect teacher learning.

On-the-job learning opportunities. Teachers' on-the-job learning opportunities may occur throughout the school day in a wide variety of activities, including conversations between teachers in the hallway, interactions with students, planning sessions with colleagues, and meetings with parents. While we acknowledge that all of these instances may be important to individual teachers' development, the primary focus of this piece is on those learning opportunities that involve interaction between colleagues, as studies have indicated that such activities constitute important potential learning opportunities (e.g., Little, 2002; Smylie, 1995).

The extant literature on teacher collaboration indicates that learning is fostered when teachers engage in conversations about new material (Davis, 2003), discuss strategies for effective teaching (Brownell, Yeagar, Rennels, \& Riley, 1997; Little, 2003), push one another to experiment around new initiatives (Davis, 2003), work collaboratively to share expertise (Little, 2003; Smylie, 1995), and interpret policy messages (Coburn, 2001). Recent work by Goddard, Goddard, and Tschannen-Moran (2007) suggested that "the more teachers collaborate, the more they are able to converse knowledgably about theories, methods, and processes of teaching and learning, and thus improve their instruction" (p. 879). Further, this work explored the empirical links between teacher collaboration and student achievement and, while the authors' operationalization of collaboration also included teachers' participation in school decision making, they found that higher levels of teacher collaboration were associated with higher student achievement on high-stakes tests in both math and reading, after controlling for school and individual factors (Goddard et al., 2007). In addition, Bryk et al. (1999) found that when teachers engaged in peer observation and feedback, opening their practice up to scrutiny by a colleague, they learned about their colleagues' teaching practices and were encouraged to "ask questions about their practice and to view it in a more analytic fashion" (p. 754).

Studies have also suggested that the strength of interpersonal relationships may be important when it comes to learning from interactions with colleagues. Social interactions, and specifically advice seeking, are associated with the transfer of information, which is essential for learning and knowledge development (Frank et al., 2004; Reagans \& McEvily, 2003; Uzzi, 1997). In schools, strong ties support teachers' joint sense-making about instructional policy and reform, which can enable high-fidelity implementation (Coburn, 2001; Spillane, 1999). Additionally, social interactions that span an organization's boundaries may also be important for learning because they can provide access to new information and potentially minimize conformity and group think among organizational members (Hansen, 1999; Leana \& Pil, 2006; Reagans \& McEvily, 2003; Wenger, 1998).

Organizational conditions. While some research has centered on the specific behaviors or activities involved in teachers' on-thejob learning opportunities, other work has addressed the conditions under which these opportunities typically take place-those organizational arrangements and norms that may support learning. This work often incorporates teacher behaviors (e.g., looking at student work and discussing instruction), but it also extends the discussion of on-the-job learning by defining the quality of teacher relationships and characteristics of the school organization that foster teacher learning and change (Bryk et al., 1999; Bryk \& Schneider, 2002; Coburn, 2001; Lee \& Smith, 1996; Little, 1982; Spillane, 1999). When the school is characterized by norms of trust among teachers and between teachers and administrators (Bryk \& Schneider, 2002; Tschannen-Moran, 2001), beliefs regarding collective responsibility for student learning (Lee \& Smith, 1996), 
and shared norms supporting openness and innovation (Louis et al., 1996; Rosenholtz, 1985; Scribner, Hager, \& Warne, 2002; Smylie, 1988), staff engagement in onthe-job learning activities is both more likely to occur and more likely to produce change. Studies have also shown that schools scoring high on these measures are better at raising student achievement (Louis \& Marks, 1998), fostering specific instructional changes (Bryk et al., 1999), and implementing new policies (Coburn, 2001; Spillane, 1999).

In addition, school leaders play an important role in establishing a school's organizational context. In doing so, they too may affect teacher learning in the workplace. School leaders who endorse knowledge sharing among teachers and create internal structures that promote collaboration are most effective at fostering change within their schools (Bryk et al., 1999; Bryk \& Schneider, 2002; Fullan, 2002; Youngs \& King, 2002). Furthermore, school leaders who communicate clear expectations to teachers and concrete goals for student achievement can encourage teachers to improve their practice (Leithwood, 1992). As a whole, this work suggests that teachers' onthe-job learning opportunities and their schools' organizational conditions play an important role in fostering teacher learning and change.

While the last 2 decades of research have greatly expanded the knowledge base on teacher learning, the field remains somewhat segmented into two broad areas. Although some theoretical and descriptive work on teacher learning couples teachers' formal and on-the-job learning opportunities (e.g., Corcoran, 1995a; Putnam \& Borko, 2000), empirical studies of teachers' learning opportunities have yet to do so. While we acknowledge that there may sometimes be overlap between formal and on-the-job learning opportunities, we feel that the data give us traction for looking at differences between the types of learning opportunities in which the teachers in our sample engaged in their schools. Our work seeks to understand the relative links between elementary school teachers' formal and on-the-job learning opportunities and their changes in their classroom practice in mathematics and ELA. Specifically, we explore the following questions: When teachers' formal and on-the-job opportunities to learn are taken into account, what are the relative impacts of these different activities on teacher change in instructional practice? Are these relationships mediated by teachers' perceptions of their schools' organizational conditions? Finally, are the associations between formal and on-the-job learning opportunities different for teachers' changes in math and ELA instruction?

\section{Method}

Data: Sample and Data-Collection

Procedures

The data for this study come from an evaluation of a leadership professional development program in a mid-sized urban school district in the southeastern United States. Data were collected from all of the district's 30 elementary schools. The average school had approximately 600 students, $65 \%$ black students, $28 \%$ white students, and $64 \%$ of students who qualified for free or reduced-price lunch. As part of a mixedmethod evaluation, school staff members in the 30 elementary schools were asked to complete an 18-page questionnaire. Questionnaire items were primarily closedended and asked about the school staff members' work in and out of the classroom and their involvement in school improvement efforts. The subject sections asked questions about the school as a workplace, school leadership, professional development and school change, and the respondent's background. In two open-ended questions, respondents were also asked to describe their in-school social networks by listing the names of people from whom they seek advice about mathematics and reading/language arts or English instruction. Surveys were administered to in- and 
out-of-classroom personnel, except the principals, who completed a different instrument, in each of the district's 30 elementary schools at two time points: spring of 2005 and spring of 2007. In total, 1,210 elementary school staff members responded to the survey in 2005 and 1,194 responded in 2007; respective response rates were $89 \%$ and $83 \%$. The sample for the present study was limited to selfcontained kindergarten through fifth-grade classroom teachers responsible for both math and ELA instruction. After selecting these respondents, 714 respondents from 2005 and 704 respondents from 2007 were included in the analyses.

\section{Scale Development}

Relevant to this study, the school staff questionnaire included questions regarding teachers' formal professional development, on-the-job learning opportunities, perceptions of school organizational conditions, and individual characteristics. The measures included in subsequent analyses are detailed below. In addition, specific items and alphas for each scale are included in the Appendix. All scales were reliable with alphas above or equal to .70, and most were highly reliable with alphas above .90 (Cronbach, 1951). Scales used in this study were developed using a combination of previous empirical work as well as relevant literature on each dimension of on-the-job learning opportunities and school organizational conditions. Previous scale development using the same teacher survey identified reliable constructs related to teachers' learning opportunities and the school organization (Goldring, Huff, Stitziel Pareja, \& Spillane, 2008; Goldring, Spillane, Huff, Barnes, \& Supovitz, 2006; Supovitz, Sirinides, \& May, in press). Supovitz et al. (in press) conducted confirmatory factor analysis to validate the use of similar scales from the teacher survey by examining survey items related to teacher change in instruction, collaborative discussion, peer observation and feedback, teachers' perceptions of the school environment, and principal leadership. The authors provided initial group membership, permitting items to then migrate iteratively to dimensions that better explain item variance, but no item migrated from its hypothesized dimension.

\section{Measures}

This section details the measures used in subsequent analyses. The dependent variables are Change in Math Teaching Practice and Change in ELA Teaching Practice. The measures of formal learning opportunities are Math and ELA Professional Development, Math and English Courses, and Outside Network Participation. The measures of on-the-job learning opportunities are Collaborative Discussion, Peer Observation and Feedback, and Math and ELA Advice Seeking. Finally, the measures of organizational conditions are Professional Learning Community and Principal Develops Goals. The analyses also include a number of controls, including teacher efficacy, race, and gender, as described below.

Change in math teaching practice and change in ELA teaching practice. On a 7-point scale ranging from not at all to a great deal, participants were asked to indicate how much they changed their teaching this year for the following items: student assessment, student grouping, materials used, topics covered, teaching methods used, kinds of work students do, kinds of questions asked, and understanding of the needs of individual students in their class. While the link between changes in teacher practice and student achievement is often implicit in education policies, recent work using these data has found significant links between teachers' changes in practice and student achievement on state assessments (Supovitz et al., in press). Respondents answered separately for math and ELA, and the items for each subject were then aver- 
aged to create the math change and ELA change variables.

Math professional development and ELA professional development. Math professional development and ELA professional development are two measures of teachers' formal learning opportunities. On a 4-point scale ranging from none to $8+$ sessions, participants were asked to indicate the number of professional development sessions they participated in this year in (1) mathematics teaching, and (2) reading/language arts or English teaching.

Math and English courses. Additional measures of formal learning opportunities included in subsequent analyses are teachers' coursework in math and English. On a 6-point scale ranging from none to $16+$ classes, participants were asked to indicate the number of undergraduate or graduate level courses they had taken in mathematics and in English or a related language arts field.

Outside network participation. On a 6-point scale ranging from never to 10 or more times, respondents were asked to indicate how often they participated in a network with other teachers outside of their school this year. Characterized by Garet et al. (2001) as a type of reform professional development, teacher networks outside of the school may provide teachers with opportunities to learn and may bring new information into teachers' own schools (Reagans \& McEvily, 2003; Wenger, 1998). We separate this measure from the math and ELA professional development variables because we asked separate questions about their attendance at math and English professional development and about their participation in a teacher network outside of the school.

Collaborative discussion. The collaborative discussion measure captures teachers' behaviors around conversation with colleagues regarding teaching and learning. On a 5-point scale ranging from never to more than 2 days/week, participants were asked questions regarding their conversa- tions with colleagues around issues of teaching and learning. On the same 5-point scale, respondents were also asked to indicate how often they had in-depth discussions about their teaching with another classroom teacher. Finally, on a 7-point scale ranging from never to more than once a week, respondents were asked to indicate how often they had scheduled meetings with other teachers in the school to discuss and plan curriculum or teaching approaches. Standard scores were calculated for each individual item, and items were then averaged to create the collaborative discussion variable.

Peer observation and feedback. On a 5-point scale ranging from never to more than 2 days/week, participants were asked to indicate how often they participated in four different observation and feedback activities around instruction and student work. Researchers have found that when teachers engage in observation and feedback, they may learn from colleagues and they ask more questions to improve their own teaching practice (Bryk et al., 1999; Little, 1990). Items were averaged to create the peer observation and feedback variable.

Math advice seeking and ELA advice seeking. The term out degree is a measure used in network analysis designed to capture advice-seeking interactions and opportunities for learning around specific subject matter. Respondents were asked, "To whom do you turn for advice or information about mathematics instruction?" and "To whom do you turn for advice or information about reading/language arts or English instruction?" Respondents could list up to seven different sources of information on each subject. As an indicator of tie strength, respondents were also asked to indicate how often they turned to each source for advice, ranging from yearly to daily. We call this variable advice seeking here in order to ease interpretation for the reader. The math advice seeking and ELA advice seeking measures were created by totaling the frequency with which 
subject-specific advice was sought from all sources listed. ${ }^{1}$

Professional learning community. As a measure of teachers' perceptions regarding their school's organizational conditions, respondents were asked about the school's professional learning community. On a 4-point Likert scale ranging from strongly disagree to strongly agree, teachers responded to items about teacher trust, openness between teachers, and support for teacher innovation. On a 5-point scale ranging from none to nearly all, teachers were also asked questions about how many teachers in the school took collective responsibility for school improvement and student learning. Standardized items were averaged to create the professional learning community variable. We recognize that this measure groups together a number of constructs that are often described as distinct from one another (e.g., collective responsibility and relational trust); these constructs factored together into a reliable single measure in these data.

Principal develops goals. On a 4-point Likert-type scale ranging from strongly disagree to strongly agree, respondents were also asked about how well the principal communicates and develops clear instructional goals. Sample items included whether the principal "clearly communicates expected standards for math instruction in this school" and whether the principal "communicates a clear vision for our school." We note that this variable and the professional learning community variable are measures of teachers' perceptions of the school organization, as the survey elicited respondents' feelings about their colleagues and the principal; the above on-the-job learning measures asked directly about their behaviors regarding discussion and interaction with colleagues around instruction.

Teacher efficacy. On a 4-point Likert scale ranging from strongly disagree to strongly agree, respondents were asked to respond to seven statements regarding their ability to raise student achievement and help the school improve. Items were averaged to create the teacher efficacy variable. By including this measure in our analyses, we acknowledge previous work indicating that the extent to which teachers implement changes in their classroom practice is significantly affected by their feelings of efficacy (e.g., Guskey, 1988; TschannenMoran, Hoy, \& Hoy, 1998).

Teacher characteristics. In addition to teacher efficacy, individual teacher characteristics included as control variables in subsequent analyses include number of years as a teacher, gender, race, and the teacher's class size.

\section{Data Analysis Plan}

In order to test whether the data from 2005 and 2007 were structurally different, we created a set of interactions between a 2007 dummy variable and all of the explanatory variables included in the full model. We then conducted an F-test to determine whether the interaction terms were jointly significant when added to the full model. The inclusion of the interaction terms did not significantly improve the goodness of fit for either ELA teaching practice $(F(14$, $1001)=1.10, p=n s)$ or math teaching practice $(F(14,995)=1.11, p=n s)$. These results suggest that the structure of the data from 2005 and 2007 are not sufficiently different to justify using two separate models, as the relationships between the predictors and dependent variables did not change over time. Therefore, the data were pooled and 1,418 observations were included in the sample.

To explore the relationship between teacher learning opportunities and teacher change in classroom practice, five ordinaryleast-squares multiple regression models were computed for changes in math and ELA. For each subject (math and ELA), Models 1 and 3 regressed change in teaching practice on formal and on-the-job learning opportunities, respectively. Models 2 and 4 added school fixed effects and individual teacher 
TAble 1. Pooled Sample Descriptive Statistics

\begin{tabular}{|c|c|c|c|c|c|}
\hline Variable & $\begin{array}{l}\text { Pooled Sample } \\
\text { Mean }(S D)\end{array}$ & Range & $\begin{array}{c}2005 \\
\text { Mean (SD) }\end{array}$ & $\begin{array}{c}2007 \\
\text { Mean }(S D)\end{array}$ & $p$ \\
\hline Change in math instruction ${ }^{a}$ & $3.73(1.51)$ & $1.00-7.00$ & $3.72(1.55)$ & $3.73(1.47)$ & ns \\
\hline Change in ELA instruction & $3.97(1.42)$ & $1.00-7.00$ & $4.06(1.44)$ & $3.87(1.39)$ & $p<.05$ \\
\hline Math professional development & $2.24(2.27)$ & $.00-8.00$ & $2.18(2.33)$ & $2.31(2.21)$ & $n s$ \\
\hline ELA professional development & $2.89(2.59)$ & $.00-8.00$ & $3.11(2.81)$ & $2.67(2.32)$ & $p<.01$ \\
\hline Math undergrad/grad courses & $4.21(3.34)$ & $.00-16.00$ & $4.11(3.37)$ & $4.30(3.34)$ & $n s$ \\
\hline English undergrad/grad courses & $5.54(4.08)$ & $.00-16.00$ & $5.60(4.17)$ & $5.48(3.99)$ & ns \\
\hline Outside network participation & $2.93(1.69)$ & $1.00-6.00$ & $2.93(1.71)$ & $2.91(1.66)$ & ns \\
\hline Collaborative discussion & $3.23(.82)$ & $1.10-5.33$ & $3.16(.84)$ & $3.29(.80)$ & $p<.01$ \\
\hline Peer observation and feedback & $2.10(.98)$ & $1.00-5.00$ & $2.10(1.02)$ & $2.09(.93)$ & ns \\
\hline Math advice seeking & $4.53(5.14)$ & $.00-34.00$ & $4.60(5.39)$ & $4.47(4.88)$ & $n s$ \\
\hline ELA advice seeking & $4.66(5.08)$ & $.00-34.00$ & $4.59(5.17)$ & $4.73(4.98)$ & ns \\
\hline Professional learning community & $3.21(.56)$ & $1.23-4.23$ & $3.21(.55)$ & $3.20(.57)$ & ns \\
\hline Principal develops goals & $3.36(.60)$ & $1.00-4.00$ & $2.88(.66)$ & $2.91(.66)$ & ns \\
\hline Teacher efficacy & $2.95(.42)$ & $1.14-4.00$ & $2.96(.42)$ & $2.94(.41)$ & ns \\
\hline Years experience & $13.42(9.65)$ & $1.00-47.00$ & $13.62(9.32)$ & $13.21(10.01)$ & ns \\
\hline Class size & $18.42(4.34)$ & $1.00-45.00$ & $18.39(4.50)$ & $18.44(4.18)$ & ns \\
\hline Gender & $94.1 \%$ female & & $94.6 \%$ female & $93.6 \%$ female & ns \\
\hline Race & $\begin{array}{l}71.4 \% \text { white, } \\
25.7 \% \text { black }\end{array}$ & & $\begin{array}{l}69.8 \% \text { white, } \\
26.4 \% \text { black }\end{array}$ & $\begin{array}{l}73.0 \% \text { white, } \\
23.2 \% \text { black }\end{array}$ & ns \\
\hline
\end{tabular}

Note. $-N=1,418$ (2005: 714; 2007: 704)

aFor all variables, standard scores were used in all analyses.

characteristics, including age, race, years of teaching experience, teacher efficacy, and class size, to examine the effect of these controls on the respective relationships between formal and on-the-job learning opportunities and teacher change. Including school fixed effects helped address omitted variable bias at the school level by accounting for any observed or unobserved school-level factors that may affect teacher change, as only within-school variation is used to produce model estimates. In addition, robust standard errors were calculated in Models 2 and 4 to adjust for clustering by participant ID to account for the nonindependence caused by teachers who responded in both 2005 and 2007. Finally, the full model (Model 5) included all previous variables and controls and added organizational conditions to the model.

Although using hierarchical linear modeling was considered, as teachers are nested within schools, nearly all of the variation in the dependent variables was within schools. Specifically, $96 \%$ of the variation in change in both math and ELA teaching practice was within schools.
Therefore, we concluded that using school fixed-effects models would be sufficient for addressing our research questions and more parsimonious than computing hierarchical linear models.

\section{Results}

\section{Descriptive Results}

Descriptive statistics for the measures included in this study are presented in Table 1. Sample means and standard deviations are listed for the pooled sampleused in subsequent analyses-and separately for 2005 and 2007. Although there are statistically significant differences in the mean levels of change in ELA instruction, collaborative discussion, and ELA professional development in 2005 and 2007, the previously discussed F-tests indicated that the relationships between these variables and the dependent variables did not change over time. The key variables of interest in this study-change in math and ELA teaching - indicate that, on average, teachers implemented moderate changes in their classroom practice and that there was sub- 
stantial teacher-level variation in the amount of change implemented. General trends in these data also indicate that teachers had positive attitudes toward their schools' organizational conditions, participated in collaborative discussions with colleagues more than a few times per month, engaged in peer observation and feedback a few times per year, participated in a network with teachers outside of their school two times per year, and attended more than two professional development sessions per year in both math and ELA. Additionally, teachers in this sample were relatively well experienced, with a mean of approximately 13 years of experience and a median (not listed in Table 1) of 12 years of experience.

Table 2 presents the zero-order correlations of the primary variables included in subsequent analyses. The correlations between the dependent variables-changes in math and ELA teaching practice-and teachers' formal and on-the-job learning opportunities were low to moderate, ranging from .08 to .25 . Collaborative discussion had the strongest positive association with changes in both ELA and math, at .23 and .25 , respectively. Finally, nearly all of the correlations between variables were significant at the $p<.01$ level.

\section{Regression Results}

Formal learning opportunities. Table 3 presents five multiple-regression models predicting teacher change in math and ELA teaching practice. The first four models were run in order to test the impact of adding controls for individual characteristics and school effects on the relationships between teacher change and formal and onthe-job learning opportunities. The final model was designed to test the relative impacts of all of these learning opportunities on teacher change in practice. For each subject, Models 1 and 3 are essentially unconditional models, including only the independent variables of interest-formal and on-the-job learning opportunities, respec- tively. Model 1 suggests that formal professional development has a fairly small but highly significant association with change in both math and ELA practice. This association held up well in Model 2, which added individual teacher characteristics and school fixed effects, indicating that this relationship is not strongly mediated by these controls. Specifically, a single standard deviation $(S D)$ increase in professional development is associated with approximately a $.18 S D$ and $.15 S D$ increase in the change in math and ELA teaching practice (respectively). In addition, a single $S D$ increase in outside network participation is associated with approximately a $.06 S D$ increase in the change in both math and ELA practice. The number of math courses a teacher has taken is not predictive of their change in practice for either math or ELA. Model 2 also indicates that teacher efficacy is also a statistically significant predictor of teacher change in both math and ELA teaching practice. For both subjects, Model 2 explained $12 \%$ of the variation in teacher change in practice.

On-the-job learning opportunities. Models 3 and 4 in Table 3 explore the relationship between teachers' on-the-job learning opportunities and teacher change in math and ELA classroom practice. Model 3 indicates that for both subjects, on-the-job learning opportunities are significantly associated with teachers' changes in practice. Controlling for school effects and teacher characteristics in Model 4, the relationships between change in teaching practice and collaborative discussion are statistically significant for both math and ELA, indicating that this association is not dependent upon teachers' school or individual characteristics. Collaborative discussion is the strongest predictor of teacher change, as a single $S D$ increase in collaborative discussion is associated with a .19 SD change in math and .17 SD change in ELA teaching practice. In addition, advice seeking is significantly, though relatively weakly, associated with change in practice, with a single $S D$ increase in advice seeking 


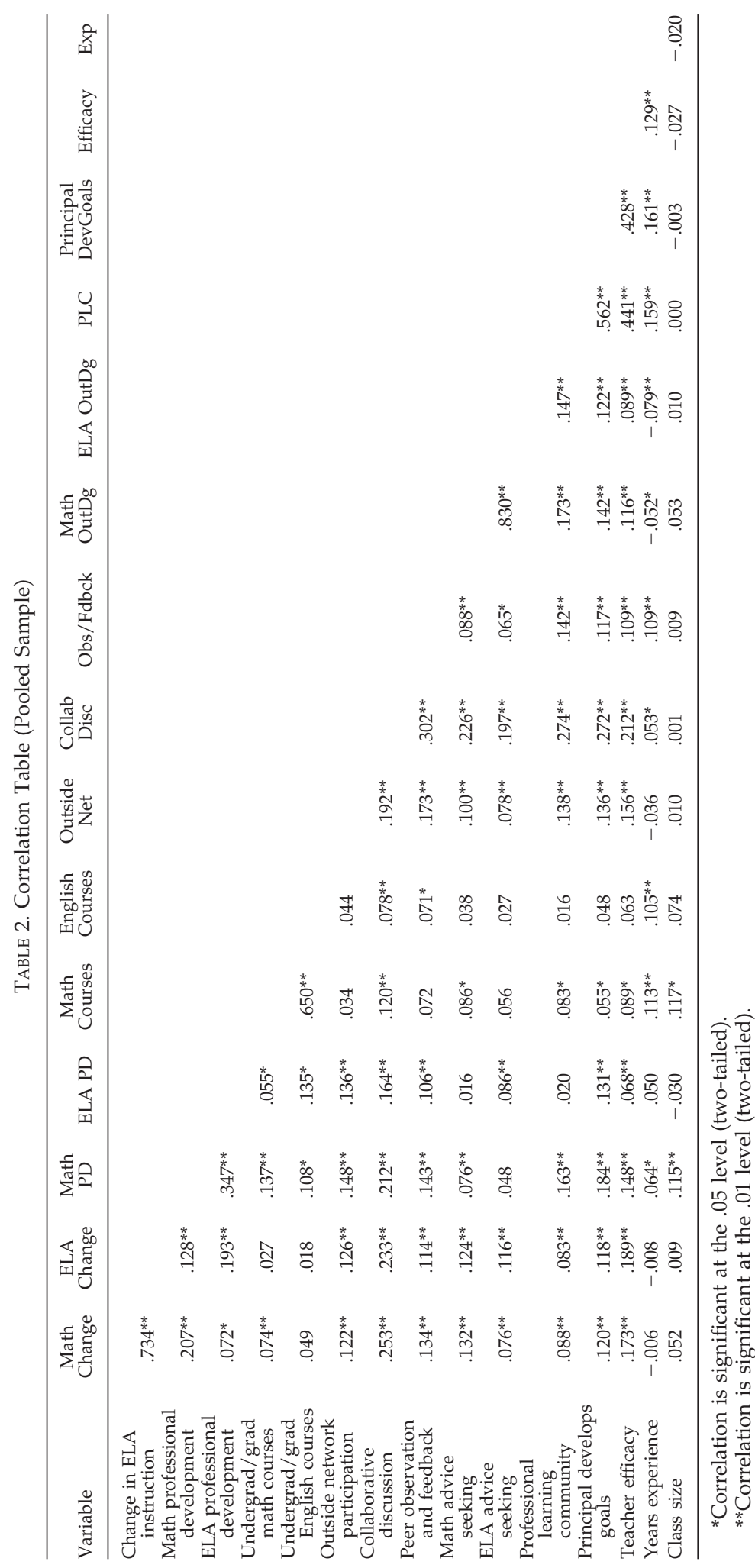




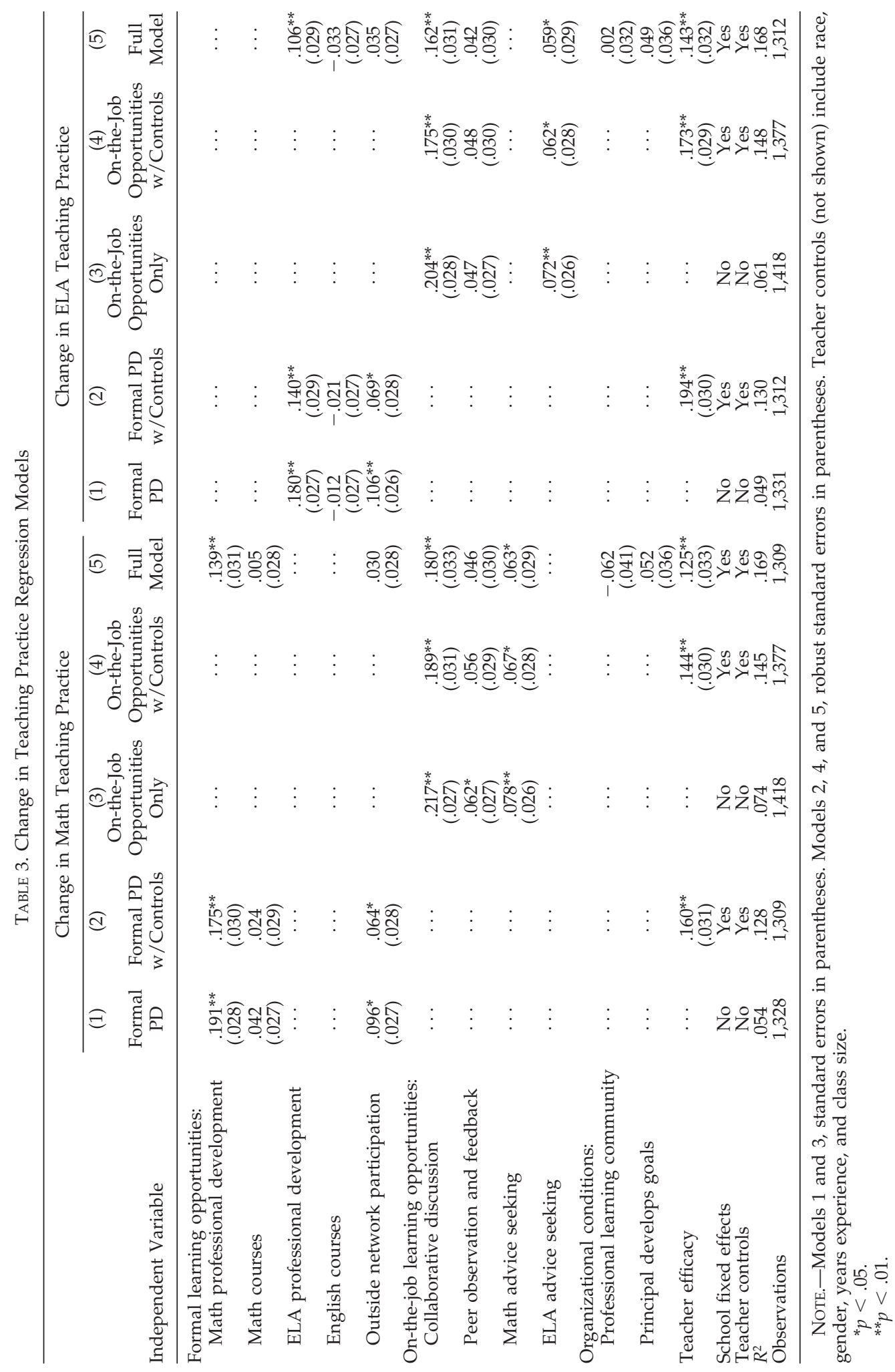


corresponding to a $.06 S D$ increase in change for both subjects. Finally, as in Model 2 for formal learning opportunities, Model 4 suggests that teachers who feel more efficacious about their work implement greater changes in their math and ELA teaching practice.

Full model. The full model included teachers' formal professional development, on-the-job learning opportunities, organizational conditions for learning, teacher controls, and school fixed effects. Simultaneously examining the relationships between teacher change, opportunities for learning, and organizational conditions, Model 5 shows that formal professional development, collaborative discussion, and advice seeking remain statistically significant predictors of teacher change in math and ELA teaching practice. Results are comparable across subject areas, as a single $S D$ increase in professional development is associated with a $.14 S D$ change in math and $.11 S D$ change in ELA teaching practice, a single $S D$ increase in advice seeking is associated with a $.06 S D$ increase in change for both subjects, and a single $S D$ increase in collaborative discussion is associated with respective increases in change in teaching practice of .18 SD and $16 S D$ for math and ELA. Furthermore, the relationship between teacher efficacy and change persists after all variables and controls were added to the full model. Post hoc significance tests indicated that there were neither significant differences by curricular domain nor between the collaborative discussion, formal professional development, and efficacy coefficients. In sum, after controlling for individual teacher characteristics and school fixed effects, both formal and on-the-job learning opportunities were statistically significant predictors of changes in teachers' math and ELA classroom practice, though we acknowledge that the coefficients are fairly small.

Robustness checks. In order to test the findings from the full school fixed-effects models, a series of robustness checks were conducted. Table 4 presents the results
TABLE 4. Robustness Checks for Pooled Sample

\begin{tabular}{|c|c|c|}
\hline Independent Variable & $\begin{array}{l}\text { Math } \\
\text { Change }\end{array}$ & $\begin{array}{l}\text { ELA } \\
\text { Change }\end{array}$ \\
\hline \multicolumn{3}{|l|}{$\begin{array}{l}\text { Formal learning } \\
\text { opportunities: }\end{array}$} \\
\hline $\begin{array}{l}\text { Math professional } \\
\text { development }\end{array}$ & $\begin{array}{l}.158^{* *} \\
(.032)\end{array}$ & $\begin{array}{l}.028 \\
(.032)\end{array}$ \\
\hline Math courses & $\begin{array}{l}.005 \\
(.028)\end{array}$ & $\ldots$ \\
\hline $\begin{array}{l}\text { ELA professional } \\
\text { development }\end{array}$ & $\begin{array}{c}-.051 \\
(.029)\end{array}$ & $\begin{array}{l}.096^{* *} \\
(.031)\end{array}$ \\
\hline English courses & $\cdots$ & $\begin{array}{c}-.035 \\
(.027)\end{array}$ \\
\hline $\begin{array}{l}\text { Outside network } \\
\text { participation }\end{array}$ & $\begin{array}{l}.031 \\
(.028)\end{array}$ & $\begin{array}{l}.032 \\
(.027)\end{array}$ \\
\hline \multicolumn{3}{|l|}{$\begin{array}{l}\text { On-the-job learning } \\
\text { opportunities: }\end{array}$} \\
\hline Collaborative discussion & $\begin{array}{l}.183^{* *} \\
(.033)\end{array}$ & $\begin{array}{l}.159^{* *} \\
(.032)\end{array}$ \\
\hline $\begin{array}{l}\text { Peer observation and } \\
\text { feedback }\end{array}$ & $\begin{array}{l}.046 \\
(.029)\end{array}$ & $\begin{array}{l}.041 \\
(.030)\end{array}$ \\
\hline ELA advice seeking & $\ldots$ & $\begin{array}{l}.060^{*} \\
(.029)\end{array}$ \\
\hline Math advice seeking & $\begin{array}{l}.062^{*} \\
(.029)\end{array}$ & $\cdots$ \\
\hline \multicolumn{3}{|l|}{$\begin{array}{l}\text { Organizational conditions } \\
\text { for learning: }\end{array}$} \\
\hline $\begin{array}{l}\text { Professional learning } \\
\text { community }\end{array}$ & $\begin{aligned}-.063 \\
(.042)\end{aligned}$ & $\begin{array}{c}-.001 \\
(.039)\end{array}$ \\
\hline Principal develops goals & $\begin{array}{l}.057 \\
(.036)\end{array}$ & $\begin{array}{l}.048 \\
(.036)\end{array}$ \\
\hline Teacher efficacy & $\begin{array}{l}.126^{* *} \\
(.033)\end{array}$ & $\begin{array}{l}.143^{* *} \\
(.032)\end{array}$ \\
\hline$R^{2}$ & .171 & .168 \\
\hline Observations & 1,309 & 1,312 \\
\hline
\end{tabular}

NOTE.-Robust standard errors in parentheses Teacher controls (not shown) include race, gender, years experience, and class size.

${ }^{*} p<.05$.

$* * p<.01$.

from the first robustness check, which aimed to verify the relationships between formal learning opportunities and teacher change. To do this, ELA formal professional development was added to the model predicting changes in math teaching practice and math professional development was added to the ELA change model. The math and ELA professional development measures were moderately correlated (.35, Table 2), but the results presented in 
TABLE 5. Robustness Checks for Teachers in Both Years

\begin{tabular}{|c|c|c|c|c|}
\hline Independent Variable & $\begin{array}{c}(1) \\
2007 \text { Math } \\
\text { Change }\end{array}$ & $\begin{array}{c}(2) \\
2005 \text { Math } \\
\text { Change }\end{array}$ & $\begin{array}{c}(1) \\
2007 \text { ELA } \\
\text { Change }\end{array}$ & $\begin{array}{c}(2) \\
2005 \text { ELA } \\
\text { Change }\end{array}$ \\
\hline \multicolumn{5}{|l|}{2005 Measures: } \\
\hline \multicolumn{5}{|l|}{ Formal learning opportunities: } \\
\hline Math professional development & $.048(.056)$ & $.172 * *(.062)$ & $\cdots$ & $\cdots$ \\
\hline Math courses & $.029(.067)$ & $.076(.054)$ & $\ldots$ & $\ldots$ \\
\hline ELA professional development & $\cdots$ & $\cdots$ & $-.052(.076)$ & $.053(.060)$ \\
\hline English courses & $\cdots$ & $\cdots$ & $.056(.062)$ & $.025(.058)$ \\
\hline Outside network participation & $-.004(.046)$ & $-.062(.073)$ & $.010(.041)$ & $-.040(.056)$ \\
\hline \multicolumn{5}{|l|}{ On-the-job learning opportunities: } \\
\hline Collaborative discussion & $.138^{*}(.058)$ & $.115+(.065)$ & $.183^{*}(.067)$ & $.103(.075)$ \\
\hline Peer observation and feedback & $-.032(.049)$ & $.044(.063)$ & $-.038(.052)$ & $.018(.061)$ \\
\hline ELA advice seeking & & & $.046(.031)$ & $.054(.057)$ \\
\hline Math advice seeking & $.049(.036)$ & $.079(.054)$ & $\ldots$ & $\ldots$ \\
\hline \multicolumn{5}{|l|}{ Organizational conditions for learning: } \\
\hline Professional learning community & $.089(.073)$ & $.009(.103)$ & $.142 *(.055)$ & $.000(.092)$ \\
\hline Principal develops goals & $.027(.074)$ & $.052(.087)$ & $.044(.068)$ & $.024(.083)$ \\
\hline Teacher efficacy & $.077(.070)$ & $.147^{*}(.062)$ & $.026(.070)$ & $.214^{* *}(.066)$ \\
\hline \multicolumn{5}{|l|}{2007 Measures: } \\
\hline \multicolumn{5}{|l|}{ Formal learning opportunities: } \\
\hline Math professional development & & $.095+(.054)$ & & $\cdots$ \\
\hline Math courses & & $-.088(.066)$ & & $\ldots$ \\
\hline ELA professional development & & $\ldots$ & & $-.003(.072)$ \\
\hline English courses & & $\ldots$ & & $-.075(.055)$ \\
\hline Outside network participation & & $-.005(.072)$ & & $-.049(.075)$ \\
\hline \multicolumn{5}{|l|}{ On-the-job learning opportunities: } \\
\hline Collaborative discussion & & $.055(.056)$ & & $.078(.069)$ \\
\hline Peer observation and feedback & & $.079(.055)$ & & $.022(.074)$ \\
\hline ELA advice seeking & & $\ldots$ & & $-.031(.061)$ \\
\hline Math advice seeking & & $.008(.036)$ & & $\ldots$ \\
\hline \multicolumn{5}{|l|}{ Organizational conditions: } \\
\hline Professional learning community & & $-.004(.072)$ & & $.022(.073)$ \\
\hline Principal develops goals & & $.116(.064)$ & & $.093(.070)$ \\
\hline Teacher efficacy & & $-.028(.048)$ & & $.032(.075)$ \\
\hline$R^{2}$ & .199 & .304 & .202 & .313 \\
\hline Observations & 412 & 385 & 416 & 394 \\
\hline
\end{tabular}

NoTE.-Robust standard errors in parentheses. Teacher controls (not shown) include race, gender, years experience, and class size.

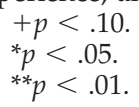

Table 4 suggest that they measure different constructs, as ELA professional development failed to predict changes in math teaching and vice-versa. Rather than being some general construct captured by both types of formal development, this robustness check suggests that teachers received specific content knowledge from these opportunities because the subject-specific training remains predictive of change in the teaching practice even when training in the other subject is entered into the model.

Table 5 presents robustness checks aimed at addressing possible simultaneity problems in the above analyses resulting from the independent and dependent variables being collected at the same time point. For example, it is possible that changes in the independent variables reflect changes in the dependent variables (e.g., Did teachers collaborate more because they had to or planned to implement changes in their practice?). In order to address this issue, the sample for the robustness checks in Table 5 was restricted to approximately 400 teachers who completed 
the school staff questionnaire in both 2005 and 2007.

In Table 5, Model 1 for both math and ELA change, lagged predictors from 2005 were used to predict 2007 change in teaching practice. The relationship between collaborative discussion and change in practice held up well in both the math and ELA models. This suggests that in the crosssectional model, the collaborative discussion variable was not reflecting changes in the dependent variable-change in classroom practice. While the relationship between formal professional development and change in practice did not hold up well in Model 1, this may not indicate simultaneity problems, but rather that teachers' professional development is not designed to have lagged effects on change in instruction over time. For example, if a teacher was trained in 2005, she would likely be expected to implement changes in her teaching practice in 2005 and not necessarily continue to make changes in 2007 based on training received 2 years earlier.

Model 2 in Table 5 regressed 2005 changes in math and ELA teaching practice on full sets of predictors from both 2005 and 2007. Including the 2007 measures of predictor variables helps control for omitted variables that might influence both the 2007 measures and the 2005 predictors and outcomes. In addition, if the 2007 variables significantly predicted changes in 2005 teaching practice, this would signal a problem with the data. This model suggests that the relationships between formal professional development, collaborative discussion, advice seeking, and teacher efficacy identified in the full model for the pooled sample (Table 3, Model 5 math) are robust for changes in math teaching practice, as the 2005 versions of these variables remained predictive over and above the future measures of these variables. However, this robustness check indicates that the relationship between organizational conditions for learning and teacher change in math may be questionable, as the 2007 ver- sion of the principal develops goals variable was more predictive of 2005 changes in teaching practice than the 2005 version of that variable for both math and ELA. For changes in ELA teaching practice, the relationships identified in the full model for the pooled sample (Table 3, Model 5 ELA) also held up, as the 2005 coefficients on professional development, collaborative discussion, and teacher efficacy were larger than the 2007 coefficients. In addition to these robustness checks, change models, which were designed to assess whether changes in learning variables predicted changes in teaching change (e.g., If a teacher attended more professional development in 2007 than in 2005, did her teaching practice change more in 2007?) were also analyzed. The results from these analyses, however, are not included here, as they neither strongly supported nor negated the findings from the pooled school fixed-effects models.

\section{Discussion}

Using a sample of elementary school teachers responsible for both math and ELA instruction, this study examined the empirical links between teachers' formal professional development and on-the-job learning opportunities and teacher change. For a large sample of elementary school teachers, school fixedeffects models provide empirical confirmation that self-reports of both formal and onthe-job learning opportunities are statistically significant predictors of teachers' reported changes in math and ELA classroom practice. We believe this study adds an important and practical contribution to the literature, as our results suggest that concurrently exploring different types of teacher learning opportunities is worthwhile.

First, our results show that considering both formal professional development and on-the-job learning opportunities and their relations with teacher change is meaningful. This finding has implications for conceptions about what constitutes a produc- 
tive opportunity for teacher learning and challenges policymakers' reliance on formal professional development as the primary mechanism for improving the quality of in-service teachers. In addition, Hill (2004) suggested that a major gap in the literature on teacher professional development is that few studies examine the development opportunities of typical teachers, and we feel that we have helped address that gap by exploring the learning opportunities of a sample of self-contained elementary school teachers in one district.

Extant literature has jointly discussed teachers' formal professional development and on-the-job learning opportunities in reviews and theoretical pieces. For example, Putnam and Borko (2000) posited that a combination of approaches to teacher learning and change involving formal professional development and engagement in instructional discourse with colleagues may best foster changes in teachers' practices. The major contribution of this study is that it substantiates the notion that both types of opportunities support teacher learning and help facilitate teachers' changes in practice. Although this study did not include a follow-up assessing the quality of teachers' changes in practice, we believe these changes to be beneficial, as other work with these data has found teachers' reported changes in practice to be linked to improvements in student achievement (Supovitz et al., in press).

Among the on-the-job learning opportunities explored in this study, collaborative discussion between teachers was the strongest predictor of teacher change in math and ELA classroom practice. While other studies have not examined the relative effects of the different on-the-job learning opportunities explored here, the notion that collaborative discussion between teachers plays an important role in their development is well supported by previous work suggesting that collaboration improves teachers' knowledge base for teaching (Brownell et al., 1997; Goddard et al., 2007). One additional conceivable explanation for the link between collabora- tive discussion and teacher change in practice is that when teachers choose to engage with colleagues, they do so around subject matter that is directly relevant to their current teaching practice. As previously discussed, work on formal professional development has suggested that activities closely tied to teachers' daily work and focused on specific content are more likely to facilitate learning and change (Desimone, Porter, Garet et al., 2002; Garet et al., 2001; Porter et al., 2000; Smylie, 1995), so although the present data did not include this information, it is plausible that the same is true for teachers' on-the-job collaborative discussion.

In addition to informing our understanding of the potential value of on-thejob learning opportunities for teacher learning and change, this study has implications regarding spending on teachers' formal professional development. Across the United States, district estimates of spending on teachers' formal professional development range from $2 \%$ to $5 \%$ of the yearly budget being spent on the activities alone, and this amount nearly doubles when salary increases awarded for educational attainments are also considered (CPRE, 1996). Financial support varies widely at the state level, but even conservative estimates suggest that most states contribute millions of dollars to teacher professional development (CPRE, 1996; Ward, St. John, \& Laine, 1999). One fundamental problem is that very little is known about the tangible returns to this investment. The evidence we do have suggests that the majority of these funds are spent on formal learning opportunities for teachers that have little impact on their classroom practice (Corcoran, 1995a; Desimone, Porter, Garet et al., 2002; Garet et al., 2001). The results from this study provide evidence that teachers do engage in valuable formal learning opportunities, as content-specific professional development is linked to teachers' changes in classroom practice.

The results of this study also suggest, however, that there may be additional strategies for augmenting teacher learning 
and improving the quality of public school teachers than are currently promoted by education policy. If the learning opportunities in which teachers engage in their schools are at least as effective at fostering change as costly formal learning opportunities, then it may be worthwhile to incorporate more on-the-job learning opportunities into teachers' work lives. The notion that teachers should be provided with more opportunities to learn from and with their colleagues through collaboration is not a new concept within the field of education. In fact, researchers and some reformers have been advocating setting aside time for teacher collaboration for many years (e.g., Darling-Hammond, 1996; Darling-Hammond \& McLaughlin, 1995; Hiebert \& Stigler, 2000; Little, 1982; Rosenholtz, 1989b; Smylie, 1994), and some local school systems have already instituted this practice (Rosenholtz, 1989a; Spillane, Mesler, Croegaert, \& Sherer Zoltners, 2009). These strategies for teacher learning and change rarely find their way into education policy, especially at the state and federal levels. There are, however, a handful of states that have recognized the potential value of on-the-job learning opportunities by including them in teacher policies. For instance, rather than requiring that teachers accumulate professional development hours for recertification solely through formal learning opportunities, Virginia, Vermont, and a few other states also allow peer observation and participation in collaborative curriculum development to count toward recertification (CPRE, 1996).

A key issue here, however, concerns how policymakers at the federal, state, and district levels might work to influence on-the-job learning opportunities for teachers, and which level of the educational system might be best positioned to do so. We acknowledge that it may be easier for policymakers to mandate that teachers spend a specified number of hours in formal learning activities than to require them to engage in on-the-job learning opportunities. The results of this work may therefore be especially relevant to the work of school leaders, who may intentionally structure teachers' work in order to allow them opportunities to engage in discussion and joint work with colleagues (Spillane et al., 2009). This is not to say that school leaders can easily compel teachers to engage in productive collaboration, as some collaboration may increase conflict (Achinstein, 2002), but they may use different strategies to shape teachers' schedules and promote activities that have been shown to cultivate productive teacher collaboration, such as teaming and appointing teacher leaders (DragoSeverson, 2007). In addition, while they were not a substantial factor in teachers' learning opportunities in the district we studied, ${ }^{2}$ coaches may play an important role in facilitating teachers' on-the-job learning opportunities (Showers \& Joyce, 1996).

In addition to providing empirical evidence that both formal and on-the-job learning opportunities are significantly associated with teachers' changes in instructional practice, we found two relatively unexpected results. First, the results suggest teachers' perceptions of their schools' organizational conditions have markedly different relationships to change than their on-the-job behaviors. In addition, while we expected that the relationships between teacher learning opportunities might differ between math and ELA, we did not find significant differences between the two subjects.

Previous work on professional community has often combined measures of teachers' perceptions about their school's organizational climate, including teachers' feelings about trust between teachers and staff members' collective responsibility for student learning, and measures of teachers' collegial behaviors, including the frequency with which teachers engage in collaboration and peer observation (e.g., Bryk et al., 1999; Louis \& Marks, 1998; Louis et al., 1996). While prior studies have found that a meaningful scale is formed when these types of items are combined, the related items in this data set did not form a reliable scale. In separating teach- 
ers' perceptions about the organizational climate from their collegial interactions, this study found that, in a sense, actions speak louder than words. One contribution of this study is the finding that teacher perceptions and actions may operate in distinct ways with respect to their relationships to teachers' changes in instructional practice. Specifically, teachers' on-the-job behavior was consistently related to their changes in practice, and this relationship was not affected by the introduction of teachers' perceptions of organizational conditions into the model.

With regard to curricular domain, this study suggests that associations between learning opportunities and changes in practice are comparable in math and ELA, which is in itself a notable finding given the literature outlining variation in teacher practice by subject (e.g., Drake et al., 2001; Siskin, 1991; Stodolsky, 1988; Stodolsky \& Grossman, 1995). Prior work indicated that advice seeking may be more influential in teachers' math practice than in other subject areas, as Stodolsky and Grossman (1995) found that secondary teachers' lessons were more coordinated with their colleagues in math than in other subjects. Stodolsky and Grossman's work, however, focused specifically on high school teachers who were specialized in their teaching assignments. Our findings suggest that this may not be true for self-contained elementary school teachers who are responsible for teaching both subjects, but further work with a larger sample might better detect differences by curricular domain. It is also plausible that the current policy environment, which places a dual emphasis on math and ELA, has led to teachers treating the two subjects more similarly than they once did.

\section{Limitations}

The data for this study include detailed measures of many aspects of teachers' work practice. This study does, however, have limitations. First, the data set includes rich information regarding teachers' onthe-job learning opportunities, but its mea- sures of formal learning opportunities are less detailed. While one of the questionnaire's strengths is that it asks about formal development sessions addressing specific subject matter, one limitation is that it does not differentiate between varying formal professional development formats (e.g., reform vs. traditional) or include detailed information on the timing of graduate coursework. Another potential limitation is that the data are self-reports of teacher change and participation in learning opportunities. Mayer (1999) reported that while teacher self-reports of classroom practice may be quite reliable, survey instruments are unable to precisely measure the quality of teachers' practice. Nonetheless, as mentioned previously, other work with these data has found statistically significant relationships between teacher change and student achievement (Supovitz et al., in press). Finally, the relationships discussed herein are correlational, and although a number of robustness checks have been conducted to assess the strength of the relationships in the school fixed-effects models, causal arguments are beyond the scope of the data.

\section{Conclusion and Future Research}

By concurrently analyzing the empirical relationships between elementary school teachers' formal professional development and on-the-job learning opportunities and change in math and ELA instruction, this article extends the existing research on teacher learning and change. Its findings indicate that the opportunities in which teachers engage within their school buildings are at least as predictive of teacher change as are the subject-specific formal professional development sessions they attend. Furthermore, this study suggests that it may be worthwhile for both school leaders and policymakers to pay more attention than they traditionally have to on-the-job learning opportunities by allocating time for teachers to collaborate or adjusting policy levers regarding teacher recertification. 
Future research in this area should explore the relative relationships between different types of formal learning opportunities (e.g., workshops vs. ongoing mentoring, conferences vs. teacher networks, etc.), on-thejob opportunities, and teacher change. Conducting such an analysis may determine that the relationship between formal professional development and teacher change identified by this study underestimated the effects of certain activities, but overestimated the effects of others. Additional next steps include exploring the links between teacher learning opportunities, teacher change, and student achievement. Gaining a better understanding of the relative impacts of these opportunities on raising student achievement-the primary goal of many education policieswill provide useful information to teachers, school leaders, and policymakers. Finally, because this study focused only on elementary school teachers, middle and high school teachers should be included in subsequent analyses, as the relationships between the primary variables of interest may differ significantly by school level. In addition to the knowledge contributed to the field by the present study, this future research will help answer important questions regarding the most effective strategies for improving the knowledge and skills of in-service teachers so that they are better equipped to improve student outcomes.

\section{Appendix}

\section{School Staff Questionnaire Items}

Math Change $(\alpha=.95)$

Please indicate how much you changed the following aspects of your math teaching this year:

\footnotetext{
Student assessment

Student grouping

Materials used

The topics covered

The teaching methods you use

The kinds of work you have students do

The kinds of questions you ask students

Your understanding of the needs of in-

dividual students in your class
}

\section{ELA Change $(\alpha=.93)$}

Please indicate how much you changed the following aspects of your reading/language arts or English teaching this year:

Student assessment

Student grouping

Materials used

The topics covered

The teaching methods you use

The kinds of work you have students do

The kinds of questions you ask students

Your understanding of the needs of in-

dividual students in your class

\section{Collaborative Discussion $(\alpha=.90)$}

This school year, how often have you had conversations with colleagues about the following topics:

\footnotetext{
What helps students learn the best

Development of new curriculum

The goals of this school

Managing classroom behavior

Your reading/language arts of English instruction

Your math instruction

Content or performance standards in reading/language arts or English

Content or performance standards in math
}

This school year, how often did you have scheduled meetings with other teachers in this school to discuss and plan curriculum or teaching approaches?

This school year, how often did you have indepth discussions about your teaching with the following people:

Another classroom teacher

Peer Observation and Feedback $(\alpha=.84)$

This school year, how often did you observe any of the following people teach?

Another classroom teacher

This school year, how often did the following people observe you teach?

Another classroom teacher

This school year, how often did the following people give you feedback after observing you teach? 
Another classroom teacher

This school year, how often did the following people review your students' work?

\section{Another classroom teacher}

Professional Learning Community $(\alpha=.94)$ Indicate the extent to which you agree or disagree with each of the following statements about the school in which you work:

Teachers in this school respect colleagues who are expert in their craft

Teachers in this school trust each other

Teachers in this school really care about each other

Teachers respect other teachers who take the lead in school improvement efforts

Many teachers openly express their professional views at faculty meetings

Teachers in this school are willing to question one another's views on issues of teaching and learning

We do a good job of talking through views, opinions, and values

Teachers are expected to continually learn and seek out new ideas in this school

Teachers are encouraged to experiment in their classrooms in this school

Teachers are encouraged to take risks in order to improve their teaching

How many teachers in this school do the following:

Take responsibility for helping one another do well

Help maintain positive student behavior in the entire school

Take responsibility for improving the overall quality of teaching in the school

Principal Develops Goals $(\alpha=.93)$

Mark the extent to which you disagree or agree with each following statements about the principal in this school:

Clearly communicates expected standards for reading/language arts or English instruction in this school

Clearly communicates expected standards for math instruction in this school

Encourages teachers to raise test scores
Makes clear to the staff his or her expectations for meeting instructional goals

Communicates a clear vision for our school

Communicates clear standards for student learning

Teacher Efficacy $(\alpha=.70)$

I am capable of making the kinds of changes expected in this school

The kinds of changes expected in this school are helping my students reach higher levels of achievement

I strongly value the kinds of changes expected in this school

If I try really hard, I can get through to even the most difficult and unmotivated students

I am uncertain how to teach some of my students [Scale reversed]

My students' peers influence their motivation more than I do [Scale reversed]

Most of a student's performance depends on the home environment, so I have limited influence [Scale reversed]

Notes

Work on this article was supported by the Distributed Leadership Studies with funding from the Institute for Education Sciences (grant R305E040085) and the National Science Foundation (grant 0412510). We are grateful to our colleagues on the study for their help with data collection and data analysis: Carol Barnes, Eric M. Camburn, Lisa Dorner, Ellen Goldring, Jonathon Supovitz, Jason Huff, Henry May, Beth Sanders, James Sebastian, James Pustejovsky, and Amber Stitziel Pareja. We are grateful to Greg Duncan for his comments on an earlier draft of this article. All opinions and conclusions or recommendations expressed in this paper are those of the authors and do not necessarily reflect the views of any of the funding agencies. Address all correspondence to Leigh Mesler Parise at 1-mesler@northwestern.edu.

1. For example, if a respondent sought math teaching advice from two colleagues daily (weight of 5), one colleague monthly (weight of 3 ), and one colleague yearly (weight of 1), the respondent's weighted math advice seeking measure would be $14(5+5+3+1)$.

2. Half of the teachers in the sample did not interact with a coach during the school year, and those teachers who did work with a coach did so 
infrequently (only $20 \%$ interacted with a coach more than a few times per year).

\section{References}

Achinstein, B. (2002). Conflict amid community: The micropolitics of teacher collaboration. Teachers College Record, 104(3), 421-455.

Birman, B. F., Desimone, L., Porter, A. C., \& Garet, M. S. (2000). Designing professional development that works. Educational Leadership, 57(8), 28-33.

Borko, H. (2004). Professional development and teacher learning: Mapping the terrain. Educational Researcher, 33(8), 3-15.

Brownell, M. T., Yeagar, E., Rennels, M. S., \& Riley, T. (1997). Teachers working together: What learning educators and researchers should know. Teacher Education and Special Education, 20, 340-359.

Bryk, A. S., Camburn, E., \& Louis, K. S. (1999). Professional community in Chicago elementary schools: Facilitating factors and organizational consequences. Educational Administration Quarterly, 35(5), 751-781.

Bryk, A. S., \& Schneider, B. L. (2002). Trust in schools: A core resource for improvement. New York: Russell Sage.

Carpenter, T. P., Fennema, E., Peterson, P. L., Chiang, C. P., \& Loef, M. (1989). Using knowledge of children's mathematics thinking in classroom teaching: An experimental study. American Educational Research Journal, 26(4), 499-531.

Coburn, C. E. (2001). Collective sensemaking about reading: How teachers mediate reading policy in their professional communities. Educational Evaluation and Policy Analysis, 23(2), 145-170.

Cohen, D. K., \& Barnes, C. A. (1993). Pedagogy and policy. In D. K. Cohen, M. W. McLaughlin, \& J. E. Talbert (Eds.), Teaching for understanding: Challenges for policy and practice (pp. 207-239). San Francisco: Jossey-Bass.

Cohen, D. K., \& Hill, H. C. (2002). Learning policy: When state education reform works. New Haven, CT: Yale University Press.

Corcoran, T. C. (1995a). Helping teachers teach well: Transforming professional development. Philadelphia: University of Pennsylvania.

Corcoran, T. C. (1995b). Transforming professional development for teachers: A guide for state policymakers. Washington, DC: National Governors' Association.

CPRE (1996). Policies and programs for professional development of teachers: Profiles of the states.
Philadelphia: Consortium for Policy Research in Education.

Cronbach, L. J. (1951). Coefficient alpha and the internal structure of tests. Psychometrika, 16(3), 297-334.

Darling-Hammond, L. (1996). The quiet revolution: Rethinking teacher development. Educational Leadership, 53(6), 4-10.

Darling-Hammond, L. (2000). Teacher quality and student achievement: A review of state policy evidence. Education Policy Analysis Archives, 8(1), 1-49.

Darling-Hammond, L., \& McLaughlin, M. W. (1995). Policies that support professional development in an era of reform. Phi Delta Kappan, 76(8), 597-604.

Davis, K. S. (2003). "Change is hard": What science teachers are telling us about reform and teacher learning of innovative practices. Science Education, 87(1), 3-30.

Desimone, L., Porter, A. C., Birman, B. F., Garet, M. S., \& Yoon, K. S. (2002). How do district management and implementation strategies relate to the quality of the professional development that districts provide to teachers? Teachers College Record, 104(7), 1265-1312.

Desimone, L., Porter, A. C., Garet, M. S., Yoon, K. S., \& Birman, B. F. (2002). Effects of professional development on teachers' instruction: Results from a three-year longitudinal study. Educational Evaluation and Policy Analysis, 24(2), 81-112.

Drago-Severson, E. (2007). Helping teachers learn: Principal leadership for adult growth and development. Teachers College Record, 109(1), 70-125.

Drake, C., Spillane, J. P., \& Hufford-Ackles, K. (2001). Storied identities: Teacher learning and subject-matter context. Journal of Curriculum Studies, 33(1), 1-23.

Eraut, M. (2004). Informal learning in the workplace. Studies in Continuing Education, 26(2), 247-273.

Eraut, M., \& Hirsh, W. (2007). The significance of workplace learning for individuals, groups, and organisations. Oxford: University of Oxford, SKOPE.

Feiman-Nemser, S. (2001). From preparation to practice: Designing a continuum to strengthen and sustain teaching. Teachers College Record, 103(6), 1013-1055.

Frank, K. A., Zhao, Y., \& Borman, K. (2004). Social capital and diffusion of innovations within organizations: The case of computer technology in schools. Sociology of Education, 77, 148-171.

Fullan, M. (2002). The change leader. Educational Leadership, 59(8), 16-20. 
Garet, M. S., Cronen, S., Eaton, M., Kurki, A., Ludwig, M., Jones, W., et al. (2008). The impact of two professional development interventions on early reading instruction and achievement. Washington, DC: NCEE.

Garet, M. S., Porter, A. C., Desimone, L., Birman, B. F., \& Yoon, K. S. (2001). What makes professional development effective? Results from a national sample of teachers. American Educational Research Journal, 38(4), 915-945.

Goddard, Y., Goddard, R., \& Tschannen-Moran, M. (2007). A theoretical and empirical investigation of teacher collaboration for school improvement and student achievement in public elementary schools. Teachers College Record, 109(4), 877-896.

Goldhaber, D. D., \& Brewer, D. J. (1998). When should we reward degrees for teachers? Phi Delta Kappan, 80(2), 134-138.

Goldring, E., Huff, J., Stitziel Pareja, A., \& Spillane, J. P. (2008, March). Measuring principals' content knowledge of learning-centered leadership. Paper presented at the meeting of the American Educational Research Association, New York.

Goldring, E., Spillane, J. P., Huff, J., Barnes, C. A., \& Supovitz, J. (2006, April). Measuring the instructional leadership competence of school principals. Paper presented at the meeting of the American Educational Research Association, San Francisco.

Guskey, T. R. (1988). Teacher efficacy, selfconcept, and attitudes toward the implementation of instructional innovation. Teaching and Teacher Education, 4(1), 63-69.

Guskey, T. R. (2002). Professional development and teacher change. Teachers and Teaching, 8(3), 381-391.

Hansen, M. T. (1999). The search-transfer problem: The role of weak ties in sharing knowledge across organization subunits. Administrative Science Quarterly, 44(1), 82-85.

Hiebert, J., \& Stigler, J. W. (2000). A proposal for improving classroom teaching: Lessons from the TIMSS video study. Elementary School Journal, 101(1), 3-20.

Hill, H. C. (2004). Professional development standards and practices in elementary school mathematics. Elementary School Journal, 104(3), 215-231.

Hill, H. C. (2007). Learning in the teaching workforce. The Future of Children, 17, 111-127.

Leana, C. R., \& Pil, F. K. (2006). Social capital and organizational performance: Evidence from urban public schools. Organization Science, 17(3), 353-366.

Lee, V. E., \& Smith, J. B. (1996). Collective responsibility for learning and its effects on gains in achievement for early secondary school students. American Journal of Education, 104(2), 103-147.

Leithwood, K. (1992). The move toward transformational leadership. Educational Leadership, 49(5), 8-12.

Lieberman, A. (1995). Practices that support teacher development. Phi Delta Kappan, 76(8), 591-596.

Little, J. W. (1982). Norms of collegiality and experimentation: Workplace conditions of school success. American Educational Research Journal, 19(3), 325-340.

Little, J. W. (1990). The persistence of privacy: Autonomy and initiative in teachers' professional relations. Teachers College Record, 91(4), 509-536.

Little, J. W. (1993). Teachers' professional development in a climate of educational reform. Educational Evaluation and Policy Analysis, 15(2), 129-151.

Little, J. W. (2002). Locating learning in teachers' communities of practice: Opening up problems of analysis in records of everyday work. Teaching and Teacher Education, 18(8), 917-946.

Little, J. W. (2003). Inside teacher community: Representations of classroom practice. Teachers College Record, 105(6), 913-945.

Louis, K. S., \& Marks, H. M. (1998). Does professional community affect the classroom? Teachers' work and student experiences in restructuring schools. American Journal of Education, 106(4), 532-575.

Louis, K. S., Marks, H. M., \& Kruse, S. (1996). Teachers' professional community in restructuring schools. American Educational Research Journal, 33(4), 757-798.

Mayer, D. (1999). Measuring instructional practice: Can policymakers trust survey data? Educational Evaluation and Policy Analysis, 21(1), 29-45.

McCutchen, D., Abbott, R., Green, L., Beretvas, S., Cox, S., Potter, N., et al. (2002). Beginning literacy: Links among teacher knowledge, teacher practice, and student learning. Journal of Learning Disabilities, 35(1), 69-86.

McLaughlin, M. W., \& Talbert, J. E. (2001). Professional communities and the work of high school teaching. Chicago: University of Chicago Press.

NCES (2005). Characteristics of public school teachers' professional development activities: 19992000. Washington, DC: U.S. Department of Education.

Porter, A. C., Garet, M. S., Desimone, L., Yoon, K. S., \& Birman, B. F. (2000). Does professional development change teaching practice? Results 
from a three-year study. Washington, DC: American Institutes for Research and Department of Education.

Putnam, R. T., \& Borko, H. (2000). What do new views of knowledge and thinking have to say about research on teacher learning? Educational Researcher, 29(1), 4-15.

Reagans, R., \& McEvily, B. (2003). Network structure and knowledge transfer: The effects of cohesion and range. Administrative Science Quarterly, 48(2), 240-267.

Rice, J. K. (2001). Cost framework for teacher preparation and professional development. Washington, DC: Finance Project.

Rosenholtz, S. J. (1985). Effective schools: Interpreting the evidence. American Journal of Education, 93(3), 352-388.

Rosenholtz, S. J. (1989a). Teacher's workplace: The social organization of schools. New York: Longman.

Rosenholtz, S. J. (1989b). Workplace conditions that affect teacher quality and commitment: Implications for teacher induction programs. Elementary School Journal, 89(4), 421-439.

Saxe, G. B., Gearhart, M., \& Nasir, N. S. (2001). Enhancing students' understanding of mathematics: A study of three contrasting approaches to professional support. Journal of Mathematics Teacher Education, 4, 55-79.

Scribner, J. P., Cockrell, K. S., Cockrell, D. H., \& Valentine, J. W. (1999). Creating professional communities in schools through organizational learning: An evaluation of a school improvement process. Educational Administration Quarterly, 35(1), 130-160.

Scribner, J. P., Hager, D. R., \& Warne, T. R. (2002). The paradox of professional community: Tales from two high schools. Educational Administration Quarterly, 38(1), 45-76.

Showers, B., \& Joyce, B. (1996). The evolution of peer coaching. Educational Leadership, 53, 1216.

Siskin, L. S. (1991). Departments as different worlds: Subject subcultures in secondary schools. Educational Administration Quarterly, 27(2), 134-169.

Smylie, M. A. (1988). The enhancement function of staff development: Organizational and psychological antecedents to individual teacher change. American Educational Research Journal, 25(1), 1-30.

Smylie, M. A. (1994). Redesigning teachers' work: Connections to the classroom. Review of Research in Education, 20(2), 129-177.

Smylie, M. A. (1995). Teacher learning in the workplace: Implications for school reform.
In T. R. Guskey \& M. Huberman (Eds.), Professional development in education: New paradigms and practices. New York: Teachers College Press.

Spillane, J. P. (1999). External reform initiatives and teachers' efforts to reconstruct their practice: The mediating role of teachers' zones of enactment. Journal of Curriculum Studies, 31(2), 143-175.

Spillane, J. P., Mesler, L., Croegaert, C., \& Sherer Zoltners, J. (2009). Organizational routines and school-level efforts to establish tigh coulping: Changing policy, changing work practice? Manuscript submitted for publication.

Stodolsky, S. S. (1988). The subject matters: Classroom activity in math and social studies. Chicago: University of Chicago Press.

Stodolsky, S. S., \& Grossman, P. L. (1995). The impact of subject matter on curricular activity: An analysis of five academic subjects. American Educational Research Journal, 32(2), 227-249.

Supovitz, J., Sirinides, P., \& May, H. (in press). How principals and peers influence teaching and learning. Educational Administration Quarterly.

Tschannen-Moran, M. (2001). Collaboration and the need for trust. Journal of Educational Administration, 39(4), 308-331.

Tschannen-Moran, M., Hoy, A. W., \& Hoy, W. K. (1998). Teacher efficacy: Its meaning and measure. Review of Educational Research, 68(2), 202-248.

Uzzi, B. (1997). Social structure and competition in interfirm networks: The paradox of embeddedness. Administrative Science Quarterly, 42(1), 35-67.

Ward, J. G., St. John, E. P., \& Laine, S. W. M. (1999). State programs for funding teacher professional development. Oak Brook, IL: North Central Regional Educational Lab.

Wenger, E. (1998). Communities of practice: Learning as a social system. Retrieved November 17, 2007, from www.infed.org/biblio/communities_of_practice.htm

Wilson, S. M., \& Berne, J. (1999). Teacher learning and the acquisition of professional knowledge: An examination of research on contemporary professional development. Review of Research in Education, 24, 173-209.

Youngs, P., \& King, M. B. (2002). Principal leadership for professional development to build school capacity. Educational Administration Quarterly, 38(5), 643-670. 